\title{
MEMORIAL CROSSES IN POLAND: A COMMONPLACE AND CONTESTED ELEMENT OF PUBLIC ROADS
}

\begin{abstract}
PRZYBYLSKA, L. (2015): Memorial crosses in Poland: a commonplace and contested element of public roads. Geografie, 120, No. 4, pp. 507-526. - The aim of the paper is to show spatial regularity of roadside memorialisation as well as public opinions on the phenomenon in Poland. Field studies covering 623 kilometres of public roads showed that out of 100 roadside memorials, the majority (98\%) are memorial crosses A correlation between the distribution of roadside memorials and the road category and related accident rate was noted. Internet questionnaires, on the other hand, indicated that opinions on memorial crosses are nearly equally divided in Polish society: $52 \%$ are for leaving them along roads and $48 \%$ are for their removal. Furthermore, an analysis of web discussions has shown that memorial crosses are seen by society either as traditional components of road infrastructure, or objects of religious cult, or cross-cultural markers of death and grief.

KEY WORDS: memorial crosses - memorialisation - Poland - public roads - Internet questionnaire.
\end{abstract}

This paper is part of the research project, "Sacralization of public spaces in Poland". It has been sponsored by the Polish National Science Centre according to decision number DEC2011/03/B/HS1/00394.

\section{Introduction}

The growing trend of commemorating victims of fatal road accidents has led to a significant number of publications in various journals (Henzel 1991; Clark, Franzmann 2004; Klaassens, Groote, Huigen 2009; Dickinson, Hoffmann 2010; Nešporová, Stahl 2014), collective works (Petersson 2010, Nešporová 2011, Owen 2011) and monographs (Zimmerman 1995, Everett 2002, Breen 2006). Architects, folklorists, geographers, psychologists, sociologists and other scholars study roadside memorials in terms of their appearance, location, importance for people who erected them also seeking factors contributing to their appearance in the contemporary world. Majority of publications emphasise complex motivation underpinning roadside memorialisation, whereas this paper focuses on the phenomenon from a geographical and city planning perspective.

Researches on roadside memorialisation are a part of the interdisciplinary study of deathscapes (Santino, ed. 2011; Maddrell, Sidaway, eds. 2010) or socalled "geographies of mourning and remembrance" (Maddrell 2013, p. 510) and "necrogeographic research" which seeks out the collective significance of changes in burial culture in time and space (Hupková 2013, p. 15). This paper contributes to the field of study by filling in the cognitive gap in literature on 
roadside memorials in Eastern Europe since only the situations in Czechia and Romania (Nešporová 2011; Stahl 2013; Nešporová, Stahl 2014) have been brought to light for international researchers so far.

Since 2009 the author has been observing roadside crosses, wondering as a geographer, about spatial regularities and social opinion on them. At the onset of the research presented below the author raised two key research questions:

- Where are most roadside memorials to be found (in urban or nonurban areas, along main or local roads) and what share do memorial crosses account for?

- How does society find the practice of raising memorial crosses and what meaning do they attribute to them (religious, cultural, other)?

During desk research the following hypotheses were put forward:

- The greatest number of crosses is to be found along nonurban local roads.

- Society does not find memorial crosses disturbing, because they express the attachment of Poles to the Christian tradition.

The article aims at presenting the scale of roadside memorials phenomena on Polish roads and Poles' views on the custom. Roadside memorials are described from two points of view: spatial and social relying on field research and multimedia content-analysis. The spatial perspective is understood as studying something in terms of location, distance and direction, which traditionally are associated with geography. The term social perspective does not refer to any sociological theory but is a brachylogy indicating public views and knowledge of the subject issue. In addition, this whole paper attempts to elucidate the case of Poland in comparison to research on roadside memorialization in different parts of the world.

The research location chosen in the article is the Pomorskie Voivodship, one of the 16 administrative units in the north of Poland (2.2 million inhabitants, $18,310 \mathrm{~km}^{2}$ ). In the years $2012-2014$, field studies were carried out along various public roads with the roadside memorials plotted on a map with a description of their appearance and in some cases with photos. The data was analysed on completing the field research with focus on the material aspects of roadside memorials; such as their appearance, location, presence depending on the public road category. Specific information of the roads chosen is given in the section "geographical distribution".

The dual nature of the analysis - spatial and social - is reflected in the structure of the article. The empirical study, which is presented after the theoretical framework, begins with spatial regularities of roadside memorials in the Pomorskie Voivodship followed by the analysis of the web questionnaire showing public opinions on the issue of roadside memorials in the region. The questionnaire entitled "Should memorial crosses be removed from the right-of-way?" was carried out by journalists and administration employees in November 2011 on the web portal (www.trojmiasto.pl) specialising in news in the three neighbouring cities of Gdańsk, Sopot and Gdynia (called the Gdańsk agglomeration). Therefore, the spatial aspect, mainly in quantitative terms, of the roadside memorial phenomenon is complemented by the qualitative research - the social perspective mentioned above. The author believes that the three parts of the article are complementary and help better understand the specifics of memorials in Poland. 
It must be emphasised that memorial crosses and other kinds of roadside memorials, according to Transportation Law, are illegal as it is prohibited to leave any items at the right-of-way of public roads in Poland. It should also be explained that in Poland two terms are used: apart from memorial crosses the term post accident crosses also appears. It is worth noting that both terms illustrate the function and motive underlying their erection. While the first focuses on memory as the key function and motive for putting up crosses, the second term emphasises the strict relation with the accident - the event directly responsible - and the crosses themselves document the tragic event.

It should furthermore be emphasised that the Polish case is exceptional in terms of fatal road accident statistics. According to the "Bulletin on road safety statistics in OECD countries" (2012) Poland held the shameful leading position in European countries associated in the Organisation for Cooperation and Development in terms of the number of fatalities $(4,189)$ and indicators specifying the number of deaths per 100 accidents (10) and (11) per 100,000 inhabitants. The reason put forward for the high accident rate in Poland is the regular failure to observe traffic rules, including speed limits, and driving in a state of alcohol intoxication. Numerous initiatives Poland wide on transportation like the construction of ring roads in many towns and cities, restructuring of junctions, flyovers for pedestrians, partly thanks to European Union funds, all contributed to clear improvement in road safety. The number of fatalities has been decreasing from the highest rates in the 1990s (up to 7,000 people per year), to over 5,000 fatalities in the years 2001-2008 and about 4,000 in the following years, including the lowest rate (3,571 victims) in 2012 (Road accidents - annual reports 2012). In the years 2005-2012, the number of fatalities along the Pomorskie Voivodship roads also dropped from 266 to 179 .

\section{Theoretical background}

We can distinguish two types of academic research on spontaneous roadside memorials. There are numerous case studies describing the incidence of roadside markers of death within a given area. These studies contain either a more extensive (e.g. Everett 2002) or a less extensive (e.g. Owen 2011) theoretical part. Yet another type of research is formed by papers in which roadside memorials are only one of many elements comprising issues subjected to a more thorough discussion, such as: religious landscape (Zelinsky 2010; Havlíček, Hupková 2013), deathscape (Maddrell 2013; Hupková 2013; Santino, ed. 2011; Maddrell, Sidaway, eds. 2010) or new topics in geography of religion (Kong $2001 ; 2010)$. The conceptualisation of roadside memorialization as seen in the second group of academic papers will be presented further down. Whereas the case study papers focused more on local features (physical, including technical and spatial, and social) are discussed where appropriate in the consecutive empirical parts of this article.

Roadside memorials used to be considered as part of a wider (global, social, cultural, spatial) process. In other words, general determinants hidden behind them led researchers to theoretical concepts of the phenomenon. 
Roadside shrines, flowers on the roadside, benches and trees in the park, domestic-scale statuary and plaques memorialize everyday people in public spaces in the form of affordable vernacular memorials. They are part of material memorialscape which has been flourishing during the late $20^{\text {th }}$ and early $21^{\text {st }}$ centuries. Some memorialscapes are deathscapes - "material markers of death and remembrance" (Maddrell 2013, p. 518). Memorials and the rituals associated with them form specific landscapes of loss which help us to understand the experience and meaning-making of the bereaved. Maddrell (2013, p. 517) developed the concept of absence-presence which can be summarized in the following citation: "For many individuals, knowledge and experience of someone's death can go hand in hand with a sense of their ongoing presence of the deceased, often expressed as continuing bonds. This paradoxical absencepresence is mediated through religious or secular spaces and practices, or through a mixture of both. For all, the experience and expression of absencepresence through continuing bonds is a dynamic process, which may fade, flux or persist over time."

Similarly Kong (2010) noted that roadside space is a kind of everyday life space that may occasionally take on religious functions and meanings. She argues that geographers have already come to recognize that in order to understand the place of religion in the contemporary world it is necessary to examine memorials and roadside shrines, not only the overtly religious places. The above opinions of Kong (2010) and Madrell (2013) drawing attention to the relation between memorials and religion have inspired the author to put forward the second thesis of this article.

We must not forget, as Maddrell (2013, p. 510) points out that "one person's sacred memorial can be another's litter or vandalism visited upon the landscape, and furthermore, some members of the public object to being confronted by reminders of death considered 'out of place'". Such interpretation, apart from the abovementioned meanings related to "death and remembrance", is clearly reflected in the opinion of Polish society presented further down in this article on the subject of memorial crosses standing along public roads.

In the geographical studies of death according to Hupková (2013), death is studied as a process and not as an event (as it is in demography and medicine), and emphasis is placed on what happens before and after death. She argues that in geography the burial process in its broadest sense and its effect on the landscape is more important than the process of dying, i.e. what happens before death. For Hupková (2013), roadside memorials are one of the types of deathscapes located, like cemeteries, in public spaces. Taking into account physical, symbolic and spatial aspects of any deathscapes, roadside memorials show similarity to symbolic graves met at cemeteries because they do not contain remains/ashes, but they form symbolic memorials and occupy specific places.

Santino (2011) in the introduction to the collective work on deathspace argues that many forms of spontaneous, vernacular responses to death in public space include two aspects: commemoration and performativity. The first is self-evident and the latter is a component of addressing a social and political issue; the public aspect of such memorials relates to the social conditions that caused the deaths and the political issues they refer to. He noticed that although "many roadside crosses emphasize the deaths of the individuals more 
than the conditions involved in the tragedy", elements of commemoration and performativity are present in each way people commemorate death publicly to a greater or lesser extent (Santino 2011, p. 2). The tension between these two aspects is reflected in the opinions on memorial crosses discussed further down in this paper.

The phenomenon of roadside memorials is clearly presented by Hupková (2013) and Maddrell (2013) in conjunction with wider socio-economic and cultural changes. The rise of vernacular memorials in public space "reflect a confluence of increased informalization and individualization of social identity and practices, as well as a dynamic meshing of simultaneously increased religious diversity, self-spirituality and secularization" (Maddrell 2013, p. 511). Secularization of society as a context for expanding deathscapes is also emphasised by Hupková (2013, p. 2), together with "the search for higher values outside of the confines of religion". Both researchers associate roadside memorials and other examples of spontaneous commemoration of death in public space with the rise of new types of burial customs in the UK and Czechia. High cremation rates "facilitate flexible and individualist approaches to spaces and practices of bodily disposal" (Maddrell 2013, p. 511). However, this last correlation is not observed in Poland because the cremation rate (below 15\%) is among the lowest in Europe (Hupková 2014, p. 83).

Similarly, there is no connection between roadside memorialisation, flourishing since the $1990 \mathrm{~s}$, and improving police statistics on fatality rate in Poland, referred to in the introduction. In the author's opinion, numerous roadside memorials undoubtedly sprang up as a result of regained freedom of public expression in different spheres of life (economic, political, religious, educational) after the Great Transformation in 1989. This observation is in agreement with the discussion concerning the sharp increase in the number of roadside memorials in Czechia and Romania since 1990 (Nešporová, Stahl 2014; Havlíček, Hupková 2013). To conclude, in the case of Poland however, numerous roadside memorials seem to have rather more in common with increased informalization and individualization of social practices than with the rise of new types of burial customs.

\section{Roadside memorials in space}

\subsection{Geographical distribution}

Besides national roads, there are other types of roads in Poland which are controlled at voivodship (regional), poviat and gmina (district and communal) levels. The public roads network in the Pomorskie Voivodship is ca. 19,514 km long. In 2008-2012, 28\% of road accident fatalities took place on national roads, $27 \%$ on voivodship roads, $26 \%$ on gmina and poviat roads and the remaining $19 \%$ fall to roads in the cities with poviat status, i.e. Gdańsk, Gdynia, Sopot (also called the Gdańsk agglomeration) and Słupsk (Table 1). The share of fatality rate compared with the share in the length of public roads (\%) informs about particular concentration of fatalities on national roads in the voivodship under discussion. 
Table 1 - Length and fatality rate of public roads in the Pomorskie Voivodship, Poland

\begin{tabular}{|c|c|c|c|c|c|}
\hline \multicolumn{2}{|c|}{ Reported data } & \multicolumn{4}{|c|}{ Public road category } \\
\hline & & $\begin{array}{l}\text { National } \\
\text { (State) }\end{array}$ & $\begin{array}{l}\text { Voivodship } \\
\text { (Regional) }\end{array}$ & $\begin{array}{l}\text { Poviat } \\
\text { and gmina } \\
\text { (District and } \\
\text { communal) }\end{array}$ & $\begin{array}{c}\text { Cities with poviat } \\
\text { status (Gdańsk, } \\
\text { Gdynia, Sopot, } \\
\text { Słupsk) }\end{array}$ \\
\hline A & $\begin{array}{l}\text { Share in the length of } \\
\text { public roads (\%) }\end{array}$ & 4 & 9 & 80 & 7 \\
\hline B & $\begin{array}{l}\text { Share in the fatality rate } \\
\text { in } 2008-2012(\%)\end{array}$ & 28 & 27 & 26 & 19 \\
\hline $\mathrm{A}: \mathrm{B}$ & $\begin{array}{l}\text { Road length to fatality } \\
\text { share ratio }\end{array}$ & $1: 7$ & 1:3 & $1: 0.325$ & $1: 2.7$ \\
\hline
\end{tabular}

Source: Wojewódzki Program... (2013)

Table 2 - Roadside memorials along selected public roads in the Pomorskie Voivodship, Poland

\begin{tabular}{|llrrc|}
\hline Roads & & \multicolumn{3}{c|}{ Memorials } \\
\hline Category & & Km & Total & Per 100 km of roads \\
\hline \multirow{2}{*}{ Nonurban } & National & 161 & 49 & 30 \\
& Voivodship & 157 & 9 & 6 \\
& Gmina and poviat & 152 & 6 & 4 \\
\hline Urban & National, voivodship, gmina and poviat & 153 & 36 & 24 \\
\hline Total & & 623 & 100 & 16 \\
\hline
\end{tabular}

Source: Author's field research in the years 2012-2013

National roads network is ca. $875 \mathrm{~km}$ long, which accounts for $4 \%$ of all public roads in the voivodship, but this road network alone carries ca. $30 \%$ of all road traffic in the region. Despite such insignificant share of the national roads in the whole road network in the Pomorskie Voivodship, the concentration of fatalities on them is very high. The result is attributable, according to the information provided by a document entitled "Wojewódzki Program Bezpieczeństwa Ruchu Drogowego" (Voivodship Programme of Road Safety), to the volume of traffic and the speed reached on them, rather than to the poor condition of the national roads (Wojewódzki Program... 2013).

Since available statistics focus nearly entirely on national roads, the author is unable to present the traffic intensity on the remaining road types listed in Table 1 or on the clear majority of examined road stretches included in Table 2 . It should be remembered that this part of the article is first of all aimed at answering the research question raised in the Introduction: Where are most roadside memorials to be found (in urban or nonurban areas, along main or local roads) and what share do memorial crosses account for? Accidentally discovered correlations between traffic volume vs. accidents and memorial crosses should be treated as a voice in the discussion on geographical distribution of roadside memorials and as an inspiration for further research - an in-depth analysis of the phenomenon and, in consequence, a separate paper. 
For the purpose of the study about 150 kilometres of nonurban category public roads were selected in the Pomorskie Voivodship in northern Poland: national roads $(161 \mathrm{~km})$ recommended for transit and long distance journeys as well as alternatives to toll roads, voivodship roads $(157 \mathrm{~km})$ representing the regional level of transport system importance, poviat roads and gmina roads $(152 \mathrm{~km})$ - of local significance. Additionally, urban and nonurban roads were identified. Urban roads covered the Gdańsk agglomeration which is the biggest metropolis area in northern Poland. The section length in Gdańsk $(92 \mathrm{~km})$, in Sopot $(8 \mathrm{~km})$ and in Gdynia $(52 \mathrm{~km})$ were chosen proportionally to the number of residents in particular cities (Gdańsk 465 thousand, Gdynia 249 thousand, Sopot 37 thousand). The category of urban roads covered main streets, of national, regional or local status. Thus, $1 / 3$ of national, voivodship as well as gmina and poviat roads were chosen. Table 2 and Figure 1 show spatial regularity of the phenomenon of roadside memorialisation on the example of the Pomorskie Voivodship in northern Poland.

Firstly, it is noted that the official road category has an impact on the number of road memorials ${ }^{1}$. Thus, memorials along Pomorskie national roads can be met approximately every 3 kilometres, on voivodship roads every 15 kilometres at average, and in the case of poviat and gmina roads even less, merely one every 20 kilometres. The word "merely" may sound inappropriate as it means a tragic death of at least 6 persons (six memorials along a 152 long road section).

It must be emphasised that the conclusion on the relation of roadside memorials distribution and road categories is contrary to the conclusions drawn by Henzel (1991) and Nešporová (2011). The former researcher notices that "the geographic distribution of roadside cruces over a large area of northeastern Mexico revealed that their placement is not correlated with roads having high traffic counts or dangerous conditions, but rather with their distance from cities" (Henzel 1991, p. 93). The latter researcher concluded: "Roadside memorials tend to be placed along local roads rather than along highways where it is difficult to find a suitable location for the monument and where it is usually dangerous to stop thus rendering frequent visits impossible." (Nešporová 2011, p. 341) The research conducted by the author in northern Poland shows that memorials are most common on the most dangerous national roads, slightly less frequently along less dangerous voivodship roads and the least common on the least dangerous gmina and poviat roads. This conclusion corresponds with the road length to fatality share ratio calculated in Table 1.

The second conclusion of the field research concerns the dependence of the number of memorials along roads on the area type, i.e. urban or nonurban (Table 1). While along the main streets in the Gdańsk agglomeration these can be met every $4 \mathrm{~km}$ at average (24 per $100 \mathrm{~km}$ of streets) in rural areas ${ }^{2}$ they are less common every $7 \mathrm{~km}$ (14 per $100 \mathrm{~km}$ of roads). It seems that the reason for the discrepancy can only partially be assigned to the choice of streets in the

1 Observations of Lithuanian and Latvian (regional and national roads, over $400 \mathrm{~km}$ in each state) indicate that more crosses stand in place of fatal accidents by international roads than regional (Przybylska, 2012).

2 "Rural areas" and "urban areas" are understood by the author in terms of their administrative definitions. 
Table 3 - Roadside memorials along selected national roads in the Pomorskie Voivodship, Poland

\begin{tabular}{|lcc|}
\hline National roads & Motorway A1 & No 91 \\
\hline Distance $(\mathrm{km})$ & 67 & 68 \\
Traffic (vehicles per 24 hours in thousands) & $12-15$ & $5-16$ \\
Fatalities in 2003-2012 (people killed) & 5 & 125 \\
Memorial sites & 0 & 17 \\
\hline
\end{tabular}

Source: Raport bezpieczeństwa... (2012)

city, i.e. only main streets, neglecting local streets with less traffic, because we should remember that each $1 / 3$ of length of the 3 categories of the studied roads were also taken into consideration in rural areas to allow for the comparison of results in urban and rural areas. A second justification is possible for the discrepancies in the number of memorials in two identified areas. Perhaps in the country only the local residents, who lost their lives in road accidents are commemorated as it was noticed in Owen's (2011) study of memorial crosses in Louisiana, USA. The inhabitants of the Gdańsk agglomeration and other voivodships, both business people and holiday makers, driving along Pomorskie roads on business or for leisure at the seaside or the picaresque Kaszubian Lake District, due to the distance from home do not place crosses or candles in the place of a fatal accident. What more, perhaps road service providers remove illegal memorials in nonurban areas more frequently? These deliberations require verification and further research.

Finally, a certain exception appears to be worth examining more closely (Table 3 ) at the end of the overview of geographical distribution of memorial crosses. Namely, there are spectacular differences in fatality rates and the number of roadside memorials among the roads officially classified as national. Reports of the General Directorate for National Roads and Motorways on road traffic safety in the Pomorskie network of national roads (Raport bezpieczeństwa... 2012) show (in the years 2003-2012) only 5 deaths along the only segment of a modern toll motorway in the region (called A1, not included in Table 2) and as many as 125 fatalities along the older winding road, running parallel to A1 (No. 91, included in Table 2). Interestingly, these two roads in the Pomorskie Voivodship region are similar with respect to length and traffic volume, and yet they differ fundamentally when it comes to fatality rate and the number of memorial sites (Table 3).

The results of the author's field research conducted along these roads are the following: no memorials along the A1 motorway, compared to 17 along road No. 91 (Fig. 1). The exception referred to above indicates that maybe the lower number of memorial sites along motorways does not result from difficulties to find a suitable location for them or the danger to stop at them and maintain them as Nešporová (2011, p. 341) argued in the quote cited above. The research conducted by the author of this article would rather indicate a correlation between fatality rate of a given route and the number of roadside memorials. 


\subsection{A p p e a r a n c e}

The field research in the Pomorskie Voivodship also provided information about the appearance of roadside memorials (Fig. 1). Among the 100 memorials only 2 in urban areas were not marked with a cross, which indicates a high $98 \%$ indicator of memorials in the region. Thus, the cross is the most popular sign of death in a road accident.

Secondly, all surveyed memorial crosses were Latin, what makes Polish roadside landscape a homogenous one. Religious landscapes, Everett (2002) points out, reflect diversity, negotiation and usually mirror religious hegemony. In Poland, forms of spontaneous memorialisation do reflect denominational structure of Polish society with the exceptional position of the Roman Catholic Church.

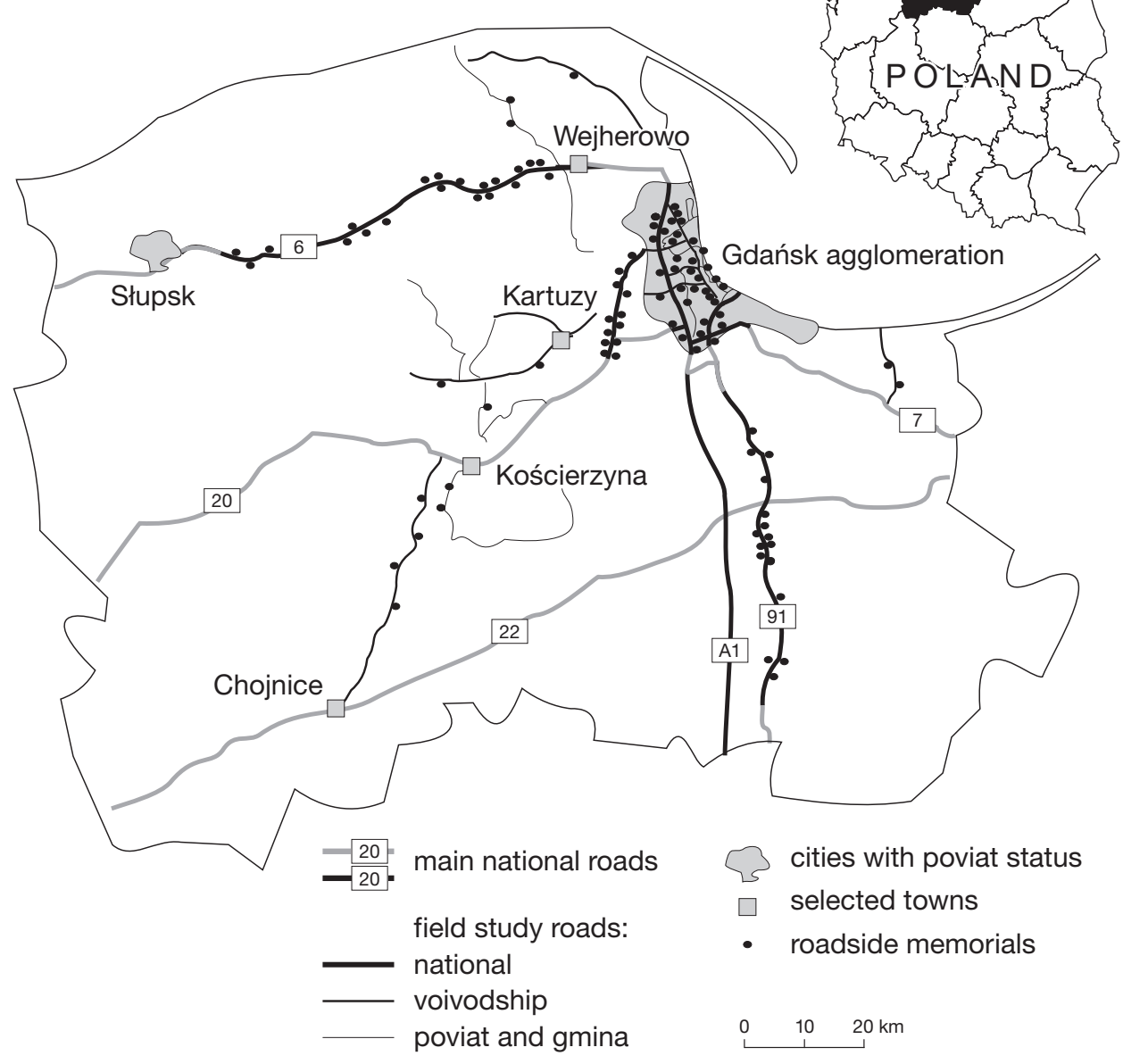

Fig. 1 - Roadside memorials along selected public roads in the Pomorskie Voivodship, Poland. Source: Author's field research in the years 2012-2013. 


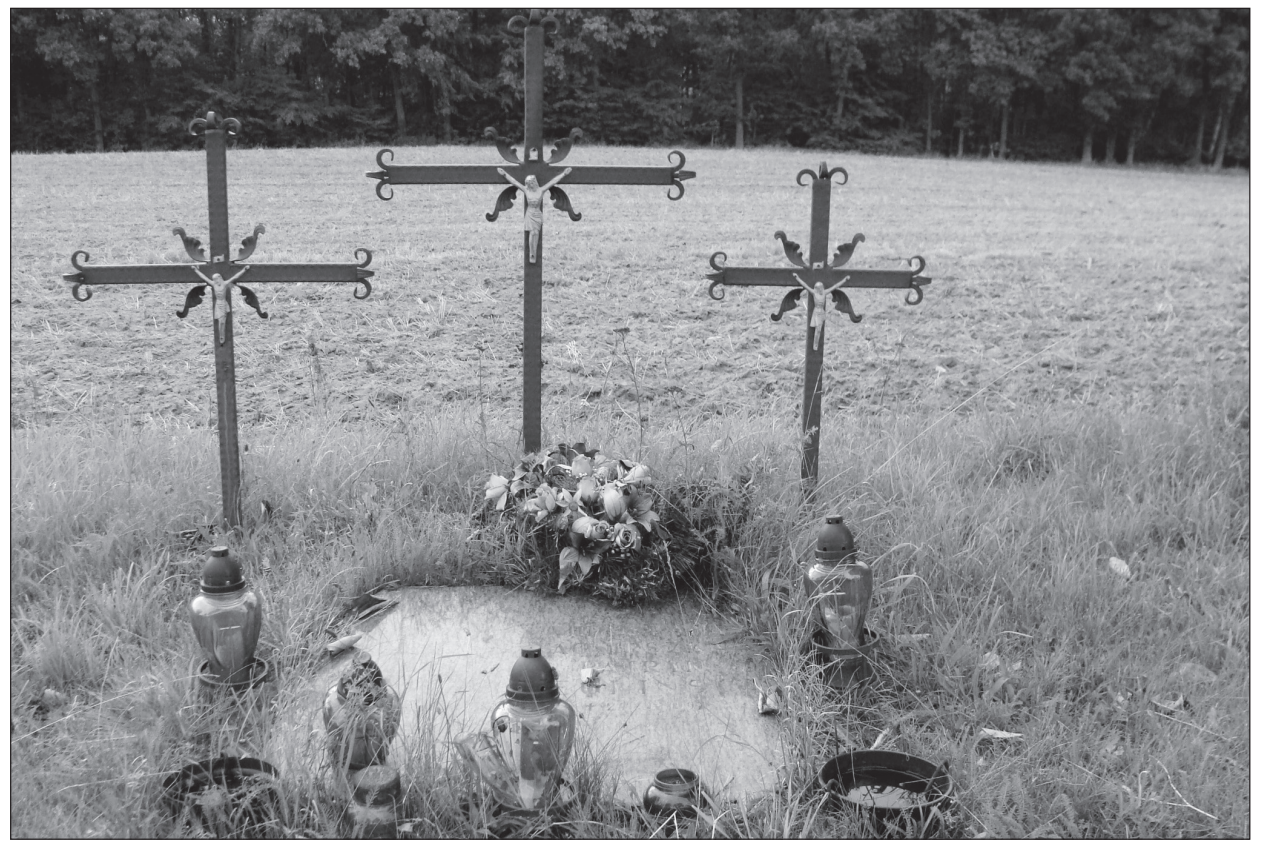

Fig. 2 - The memorial crosses along the national road no 20 in Miszewko (northern Poland). Source: Author's photo, 2011.

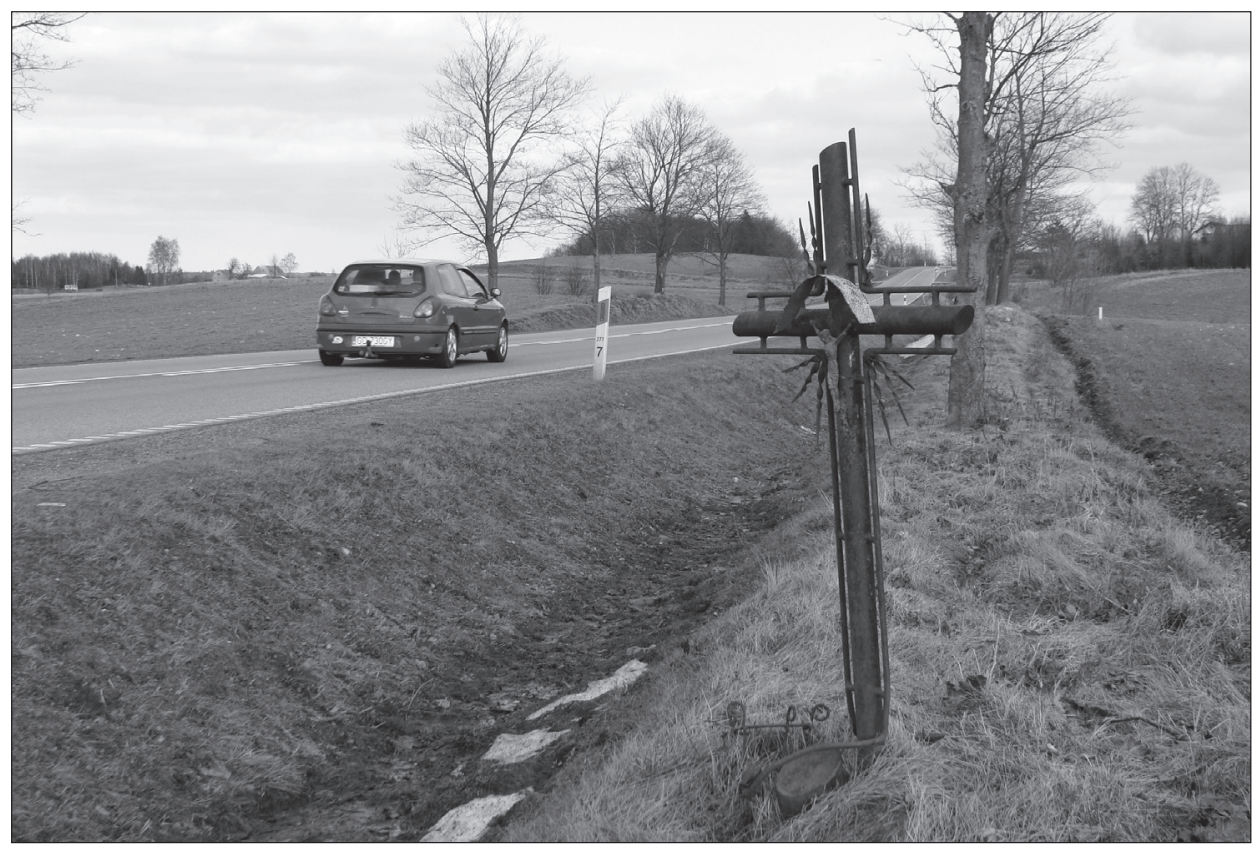

Fig. 3 - The memorial cross along the national road no 20 in Rybaki (northern Poland). Source: Author's photo, 2014. 
In 2008, the number of all registered denominations in Poland was as high as 175 and it included both churches and religious unions, however with one denomination standing out clearly - the Roman Catholic Church, with the rate of adherents amounting to 95.8\% (Wyznania religijne... 2010). This situation was described by Bilska-Wodecka (2012) as institutional religious pluralism.

This paper revealed a resemblance between the Polish and Romanian case in terms of the share of crosses among spontaneously erected memorials at the roadside. It is interesting that high official religiousness rates in Romania and low in Czechia correspond with the exceptionally high memorial crosses rate in Romania (98\%) and much lower in Czechia (65\%; Nešporová, Stahl 2014). In Poland, the high rate of memorial crosses (98\%) corresponds to the 95\% membership in the Roman Catholic Church (Statistical yearbook of the Republic of Poland 2012).

It must be emphasised that contrary to roadside memorials in Texas, USA (Everett 2002), in the Netherlands (Klaassens et al. 2009), and in Czechia and Romania (Nešporová, Stahl 2014), the vast majority of Polish memorials are not accompanied by textual messages, plaques or inscriptions left to identify the person or date of the tragedy. For example, in March 2014, as few as 4 of 17 sites in the city of Gdynia included such information.

One of the unique memorials revealing the identity of the victims and details of the date of death is located by the national road no 20 in Miszewko. The date of tragic death (24.09.1997) and names of 3 people are carved on a horizontal board accompanied by 3 metal crosses (Fig. 2). The number of crosses is also unusual because the majority of Polish memorial crosses are singular; one can occasionally see a group of 2,3 or even 4 crosses standing close to each other, symbolizing the number of the victims in one road accident.

Concluding on the appearance of roadside memorials in Poland it is worth looking at their surroundings. As in other parts of the world location of Polish roadside memorials varies from the ground close to the road to a tree, pole or barrier. It often happens that a memorial is placed in the way pretending to "look" at approaching cars. In rural areas memorial crosses are usually located beyond the ditch separating traffic lanes from the woods or fields always however remaining in the roadway (right-of-way) and in effect are put up illegally (Fig. 3).

Memorial crosses in Poland, as in many parts of the world, are usually accompanied by candles and artificial or fresh flowers (cut, potted or put in a vase); however, a detailed survey was not conducted. These same items are chosen for two surveyed secular roadside memorials, which notabene are also anonymous. Both the high share of crosses in roadside memorialisation and the exceptional anonymity seem to prove that in Poland the cross must be the most important for the bereaved and the deceased. Nevertheless, we can only guess the actual reasons for choosing crosses: are they cultural, religious or both? Separate research should further develop these guesses. Nevertheless, in the author's view the opinions of Internet users, presented further down, indirectly answer this question since they point to the presence of various meanings in the collective consciousness attributed to memorial crosses. 


\section{Memorial crosses in public's opinion}

In November 2011, an article "Will Gdańsk combat roadside memorial crosses?" was published on the website (www.trojmiasto.pl) with a questionnaire entitled "Should memorial crosses be removed from the right-of-way?". The objective of both initiatives was to collect the opinions of residents regarding crosses put up at road accident sites as the city was deliberating what action to undertake (Moritz 2011). A staff member of the Press Office in the Gdańsk Municipality informed the public that crosses had become a problem as the number of letters addressed to the municipality against roadside crosses is much higher than those supporting crosses and the law clearly prohibits the erecting of any signs, signage and symbols. It is worthwhile to look closer at the title of the website survey. In the Netherlands the key question would concern "roadside memorials" and not "memorial crosses" because of the small share of crosses (17\%) among roadside memorials, as given by Klaassens et al. (2009). The term used in the survey title by journalists and Gdańsk municipality staff revealed the aptness of the wording on roadside memorialisation in Poland, i.e. in place of road accidents we generally see crosses and there are many standing along roads as shown in the earlier part of the article. The juxtaposition of the words "combat" and "cross" in the title of the article was most probably a chosen common headlines tactic to intrigue or shock or at least catch the attention of the reader.

Within a week 3,790 opinions were submitted, which means that the public clearly was interested in the issue. Those for removing memorial crosses pointed to the illegal aspect of putting up of memorial crosses that distract drivers (29\%) were decidedly more numerous than those suggesting that the right-of-way is not a dignified location for crosses (19\%). Those against removing memorial crosses argued that crosses were a strong warning sign for drivers (44\%). The response that memorial crosses should not be removed because we have "got used to them" was selected by only $8 \%$. Thus, the website survey showed that opinions on roadside crosses were almost equally divided in Polish society: $48 \%$ for cross removal and $52 \%$ against removing them.

Apart from the "quantitative" assessment of the memorial crosses in public space we can also read on the website of trójmiasto.pl various longer and shorter spontaneous opinions of internet users on the issue (614 entries on the forum active for a week). The opinions expressed on memorial crosses sparked a wider discussion on religious values, spatial governance, the sense of authority, attitudes full of tolerance or its absolute lack, and provided an opportunity to present political likes and dislikes with comments full of humour and sharp ripostes. What more, the question on removal of post accident crosses generated responses of generic nature, great ideological and social arguments about public space and the place of religion in that space. Three main aspects were drawn from this multifaceted discussion, the spatial, ideological and cultural aspects; crosses are perceived by society as part of roadside infrastructure, religious objects, and cross-cultural markers of death and grief. 


\subsection{Crosses among annoying objects}

in a multifunctional right-of-way

Very often internet users expressed their opinions on roadside crosses at the same time complaining about the bad state of Polish roads, driving culture and the impact on safety of various structures standing along the roads such as lighted advertisements, election posters and paradoxically objects aimed at improving transport routes such as photo radars and traffic signs. Suppositions were put forward that other objects standing or discarded along the roads dissipate and annoy the drivers more than the crosses themselves. It should be emphasised that the problem of advertisement reappeared again and again like a boomerang in the discussion about crosses. Internet users find their number, content and form, and in particular the huge liquid crystal billboards, very irritating. Furthermore, advertisements became a bargaining chip both for those for and against roadside crosses. The subject of outdoor advertisements is frequently a hidden argument for removing roadside crosses. Advertisements distract and dazzle drivers and are a greater threat to traffic participants than small roadside crosses. The juxtaposition "advertisement - cross" was present as an opinion providing evidence of a unilateral, negative perception of the cross and advertisements ("Crosses just take up space along roads just like all other advertisements"). An analysis of the opinions present on the forum indicated that comments on advertisements dominated the train of thought. A question arises how the web discussion on memorial crosses would further develop if the problem of advertisements was solved.

Some of the comments indicated that the subject of roadside crosses was only a surrogate issue and evidence of the weakness of authorities to solve real problems. Many comments were addressed to administration employees or directly to the Gdańsk City President and expressed surprise that all of a sudden crosses have started disturbing the authorities, or suspicion that perhaps the article was to turn city residents against each other. Some were appalled that the municipality had "nothing better to do". The interesting point was that problems listed by internet users for the municipal authorities to solve were almost exclusively related to transport, quality of roads, their throughput capacity, public transport, signage, litter and excessive number of glaring advertisements. Suggestions also appeared that advertisements do not bother decision makers because gminas have an income from advertisements. Furthermore, the following ultimatum can clearly be read in the comments: Only when the "city" cleans and puts streets to good order (debris, car wrecks, holes in the pavement) can it start removing crosses, which are the least obstacle and the easiest to remove.

As mentioned earlier, the most popular response was not to remove the crosses as they are a strong warning for drivers. The freely expressed opinions on the forum included developing the preventive function of crosses, which were also mentioned by other researchers (Everett 2002; Dickinson, Hoffmann 2010). Opinions also appeared that "roadside crosses should evoke reflections", "crosses are a warning for the living" and that "a cross is better than any other speed limit" because "we notice the cross", and speed limits are "too common". One commenting person shared his observations about banners on viaducts of German motorways reminding drivers of road accident victims, banners 
with crosses, photos of victims and their names. Seeing the warning function of crosses and the support for leaving them on the roadside irritated some of the discussion participants. This group reminded us that the warning and speed limiting function should be assigned "only to road signs and not religious symbols put here and there". Thus, the indignation of some at substituting traffic signs by crosses or contention of others regarding the competing function of crosses and official signs. Crosses as markers of speed limits have the same number of followers and contesters.

The above manner of speaking about crosses as a counterpoint to other objects of the right-of-way corresponds to the "city planning" or "spatial management" aspect of opinions expressed. Several respondents called openly for spatial order and related respect for law. One person articulated the essence prevailing in many comments by pointing to the lack of spatial governance in the city with the following words: "Crosses erected contrary to binding regulations should vanish and advertisements be less numerous. In Poland urban planning is a mess, nobody cares about urban space... Does anybody still remember what is urban planning?"

Another short comment reading "If advertisements disappear crosses can vanish as well" can be understood as an ultimatum: Either we chose monofunctioning of the roadside landscape or agree to pluralistic functions of the right-of-way with accompanying objects and facilities strictly related to transport such as road signs and others including outdoor advertisements and memorial crosses. Thus, the web questionnaire on memorial crosses gave web users an opportunity to express opinions on the width of the right-of-way and general spatial governance in the city. Crosses were viewed as one of many ordinary or even annoying component of road infrastructure.

\subsection{Crosses as religious objects in public space}

Some of the respondents referred to the general concept of tradition in speaking about various kinds of crosses in public space in Poland (more in the next part of the article), others deliberated about crosses strictly in religious terms. An explanation for the phenomenon of memorial crosses in Poland for one person was the fact that "we are still a Catholic country". As mentioned earlier the dispute about memorial crosses in public space, i.e. the road, turned out to be a multi plot issue. At times it turned into an ideological dispute touching on religious and political aspects. Some respondents perceived the public discussion on the appropriateness of roadside crosses in the city as an attack on religious freedom, and more precisely on the rights of Christians to use the symbol, which is the most important symbol of Christianity. Opinions were also voiced that the next step would be the removal of crosses from cemeteries. The dispute on commemorating tragic deaths with a cross is for part of society "the top of an iceberg" in the fight against Christian culture, the Church, and even a sign of hate towards religious symbols and God himself.

Though the legal aspect of crosses in earlier responses relating to urban planning was termed as "breaching regulations", understood as transport law 
in Poland, in this case we see reference to moral law. What more, in their opinions on post accident crosses respondents touched on the moral dilemma and submission to authorities or own conscience, a problem disclosed in ancient times in the renown "Antigone" by Sophocles. Remarks addressed to "impenitent Catholics" did not pass unheard as evidenced by the expression of one of the respondents of a wish to live "in a country of values which are more valuable than law". The indicia of memorial crosses like the question of illegality and relation with religion is also emphasised by the following opinion calling for a clear separation of the sacredness of cross from the profane of public space: "The cross is an object of cult and as such should be present in places designated for the purpose such as churches, chapels, cemeteries. It is high time to deal with this freestyle and put our public space in order."

Studying the responses of internet users we can see that both sides of the conflict defending various kinds of crosses in public space as well as their opponents sometimes "do not mince words" in expressing their opinions. Commentators distort names of politicians, names of political and religious groups and include various invectives. Such opinions indicate that the subject gives rise to extreme emotions in society and prove that as the Polish architect Nawratek (2005) anticipated the comeback of ideological disputes on public space and public discussions both in Poland and worldwide are gaining in importance.

\subsection{Crosses as cross-cultural markers of death and grief}

Another aspect that emerged from the discussion on roadside memorials in Gdańsk referred to culture, tradition and identity. Internet users shared their remarks on similar spontaneous roadside memorials in other countries. In some cases acceptance (and argumentation) for memorial crosses followed arguments that they were part of the European heritage, a custom dating back to Roman time: "Even in the pro-communist Czechoslovakia crosses were present along roads. And in ancient Rome the dead were buried along roads and commemorating monuments were erected. This is no doubt a reference to European tradition..."

Furthermore, roadside crosses either those standing for centuries in fields and crossroads, or placed in car accident sites, according to respondents, are a fixed element of the Polish cultural landscape ${ }^{3}$; however, some extol the

3 The common site of a cross in Poland originates from 1,000 long history of Christianity on the territories inhabited by Poles, political events, as well as the high degree of religiousness among contemporary Poles. Scholars' interpretations of Polish religious society often conclude with the statement that the Roman Catholic Church has played an important role in Polish national identity throughout history. Three factors may account for this historical role, as Herbert (2010, p. 39) points out: "the disappearance of the Polish state, leaving the Catholic Church (and the Polish language) as central repositories of national identity throughout the nineteenth century, the continued denial of Polish independence under Soviet domination, and the virtual monopoly of the Roman Catholic Church in Polish religious life since 1945". Similarly Casanova (1994) claims that Church-nation 
roadside memorials as a beautiful tradition worth following, and others see it as nothing to be proud of.

Similarly, as in the earlier mentioned aspects of the discussion, also in the cultural platform the statements included the question of their legality. One of memorial cross opponents emphasised that pain and suffering are not an excuse for breaking the law with further arguments focusing on indicating the appropriate place for religious symbols (cemeteries, temples and monuments). Nevertheless, many respondents arguing "for crosses" referred to the question of respect due to the bereaved families and their way of expressing suffering and love after the loss of dear ones. There was also a statement that man is not a robot living in-line with ordinances and laws and therefore has the right to seemingly irrational behaviour and emotions provided they are of no harm to others.

In the web discussion, the erecting of crosses was also compared with the custom of putting up monuments arguing that if the famous have their monuments in the place of their death than the "average man" would also like to commemorate the death of someone close to his heart. The growing needs of this type are a challenge in the last two decades, among others, for the Department of Roads and Parks in Malmö, which is receiving a growing number of applications from individuals wishing to erect monuments in public space (Petersson 2010).

\section{Conclusions}

The thesis posed in the introduction - the greatest number of crosses is to be found along nonurban local roads - was refuted in the field study. Firstly, the research conducted by the author in northern Poland has proved that one can encounter roadside memorials almost two as often along the roads of Gdańsk agglomeration than along the countryside roads. Secondly, in the nonurban areas, roadside memorials are most common on the most dangerous national roads. Whereas they are present slightly less frequently along less dangerous voivodship (regional) roads and finally, gmina and poviat (local) roads are their least common location. Comparing this result with available data on various parameters of public roads in the region under examination, the cause of the situation should be sought in the differences in fatality rate on national, voivodship as well as on gmina and poviat roads.

The analysis of public opinions, on the other hand, show that the phenomenon of spontaneous memorial crosses in Poland evokes diversified opinions. The author's thesis posed in the introduction, according to which memorial crosses do not disturb society since they are an expression of Poles' attachment to the Christian tradition, has also been falsified. As many as $48 \%$ of people who took part in the survey "Should memorial crosses be removed from the right'-of-way?" were for the removal of crosses; they found crosses to be a possible source of chaos, a manifestation of inefficiency on the part of authorities

identification occurred between 1795 and 1914 when the Roman Catholic Church was the only institution capable of infiltrating three Participants' borders. 
in managing public space and a symbolic lack of compliance with the law separating the State from the Church. Whereas, to justify their opinion in the web discussion, the advocates of leaving crosses by the roadsides did not refer only to the Christian tradition. Some of them explained the phenomenon of memorial crosses by centuries-old tradition of putting up crosses in a Catholic country, others emphasised the right to express love and pain of losing someone dear or found them a good way to improve road safety. Thus, the proponents attribute a variety of meanings to memorial crosses: religious, cultural, and practical (preventive sign - a sign preventing further accidents).

The results of field research indicate that in northern Poland the forms of spontaneous memorialisation reflect the denominational structure of Polish society. The high rate of memorial crosses (98\%) corresponds there to the $95 \%$ membership in the Roman Catholic Church. However, public opinion does not associate a memorial cross entirely with a religious symbol. Therefore, the analysis of responses provided by Internet users leads to a conclusion that memorial crosses are an element of deathscape (Maddrell 2013, Hupková 2013) and everyday life space that occasionally take on religious functions and meanings (Kong 2010). What is clear is that in order to explain a certain christianization of roadside memorials in Polish roadscape another research would be needed. This one in turn would focus on the motivation of persons putting up roadside memorials, which can naturally become subject of another article.

\section{References:}

BILSKA-WODECKA, E. (2012): Człowiek religijny i związki wyznaniowe w przestrzeni miasta w XX i na początku XXI wieku. Instytut Geografii i Gospodarki Przestrzennej UJ, Kraków, $311 \mathrm{pp}$.

BREEN, L.J. (2006): Silenced Voices: Experiences of Grief Following Road Traffic Crashes in Western Australia. Edith Cowan University, Perth, 292 pp.

Bulletin on road safety statistics in OECD countries (2012). Instytut Transportu samochodowego, Warszawa, http://www.its.waw.pl/Stan_BRD_w_krajach_OECD,0,2431,1.html (29.3.2014).

CASANOVA, J. (1994): Public Religions in the Modern World. Chicago University Press, Chicago, 330 pp.

CLARK, J., FRANZMANN, M. (2006): Authority from Grief, Presence and Place in the Making of Roadside Memorials. Death Studies, 30, No. 6, pp. 579-599.

DICKINSON, G.E., HOFFMANN, H.C. (2010): Roadside memorial politics in the United States. Mortality, 15, No. 2, pp. 154-167.

EVERETT, H. (2002): Roadside Crosses in Contemporary Memorial Culture. University of North Texas Press, Denton, 160 pp.

HAVLÍČEK, T., HUPKOVÁ, M. (2013): Sacred Structures in the Landscape: The Case of Rural Czechia. Scottish Geographical Journal, 129, No. 2, pp. 100-121.

HENZEL, C. (1991): Cruces in the Roadside Landscape of Northeastern New Mexico. Journal of Cultural Geography, 11, No. 2, pp. 93-106.

HERBERT, D. (2010): Religion and the "Great Transformation" in Poland and East Germany. In: Herbert, D. (ed.): Religion and Social Transformations. Surrey: Ashgate, pp. 13-63.

HUPKOVÁ, M. (2013): Burial culture in the western world in the context of sociopolitical transformation, Summary of the Ph.D. thesis, Praha, http://www.religion-landscape.cz/ images/pdf/Shrnuti_dizertace_Hupkova.pdf, 29 pp. (14.3.2015). 
HUPKOVÁ, M. (2014): The link between the popularity of cremation in the Czech Republic and religious faith. Geographical Studies (Prace Geograficzne), 137, pp 69-90; DOI: 10.4467/20833113PG.14.010.2155.

KLAASSENS, M., GROOTE, P., HUIGEN, P.P.P. (2009): Roadside memorials from a geographical perspective. Mortality, 14, No. 2, pp. 187-201.

KONG, L. (2001): Mapping "new" geographies of religion: politics and poetics in modernity, Progress in Human Geography, 25, No. 2, pp. 211-233, DOI: 10.1191/030913201678580485.

KONG, L. (2010): Global shifts, theoretical shifts: Changing geographies of religion, Progress in Human Geography, 34, No. 6, pp. 755- 776. DOI: 10.1177/0309132510362602.

MADDRELL, A. (2013): Living with the deceased: absence, presence and absence-presence. Cultural geographies, 20, No. 4, pp. 501-522, DOI: 10.1177/1474474013482806.

MADDRELL, A., SIDAWAY, J.D., eds. (2010): Deathscapes. Spaces for Death, Dying, Mourning and Remembrance. Ashgate, $324 \mathrm{pp}$.

MORITZ, K. (2011): Czy Gdańsk będzie walczył z przydrożnymi krzyżami? www.trojmiasto.pl/wiadomosci/Czy-Gdansk-bedzie-walczyl-z-przydroznymi-krzyzami-n53144. html?\&vop=std\&strona=19\#opinie (20.12.2011).

NAWRATEK, K. (2005): Ideologie w przestrzeni. Próby demistyfikacji. Nomos, Kraków, 218 pp. NEŠPOROVÁ, O. (2011): Private Grief in Public Space: Roadside Memorials in the Czech Republic. In: Rotar, M., Teodorescu, A. (eds.): Dying and Death in $18^{\text {th }}-21^{\text {st }}$ Century Europe. Cambridge Scholars Publishing, Newcastle, pp. 331-350.

NEŠPOROVÁ, O., STAHL, I. (2014): Roadside memorials in the Czech Republic and Romania: Memory versus religion in two European post-communist countries. Mortality, 19, No. 1, pp. $22-40$.

OWEN, M. (2011): Louisiana Roadside Memorials: Negotiating an Emerging Tradition. In: Santino, J. (ed.): Spontaneous Shrines and the Public Memorialization of Death. Palgrave Macmillian, London, pp. 119-145.

PETERSSON, A. (2010): The Production of a Memorial Place: Materialising Expressions of Grief. In: Maddrell, A., Sidaway, J.D. (eds): Deathscapes. Spaces for Death, Dying, Mourning and Remembrance. Ashgate, Surrey, pp. 141-159.

PRZYBYLSKA, L. (2012): Krzyże i kapliczki przydrożne Litwy, Łotwy i Polski. Peregrinus Cracoviensis, 23, pp. 121-132.

Raport bezpieczeństwa ruchu drogowego na sieci pomorskich dróg krajowych (2012), https:// www.gddkia.gov.pl/userfiles/articles/r/raporty-bezpieczenstwa-ruchu-dro_302/GDDKiA_ Gdansk_Raport_BRD_2012.pdf (29.01.2014).

Road accidents - annual reports (2012), http://statystyka.policja.pl/st/ruch-drogowy/76562, Wypadki-drogowe-raporty-roczne.html (11.09.2013).

SANTINO, J. (2011): Introduction. In: Santino, J. (ed): Spontaneous Shrines and the Public Memorialization of Death. Palgrave Macmillan, New York, pp. 1-3.

SANTINO, J. ed. (2011): Spontaneous Shrines and the Public Memorialization of Death. Palgrave Macmillan, New York, 358 pp.

STAHL, I. (2013): Sudden Death Memorials in Bucharest: Mortuary Practices and Beliefs in an Urban Context. Procedia - Social and Behavioral Sciences, 92, pp. 893-898.

Statistical yearbook of the Republic of Poland (2012). Główny Urząd Statystyczny, Warszawa, http://stat.gov.pl/cps/rde/xbcr/gus/RS_rocznik_statystyczny_rp_2012.pdf, 905 pp. (15.03.2014).

Wojewódzki Program Bezpieczeństwa Ruchu Drogowego do roku 2020 - GAMBIT Pomorski 2020 (2013). Foundation for Development of Civil Engineering, Gdańsk, http://prbrd.gda. $\mathrm{pl} / \mathrm{wp}$-content/themes/prbrd/pliki/WPBRD2020.pdf, 51 pp. (21.03.2015).

Wyznania religijne. Stowarzyszenia narodowościowe i etniczne w Polsce 2006-2008 (2010). Główny Urząd Statystyczny, Warszawa, 348 pp.

ZELINSKY, W. (2010): Organizing religious landscapes. In: Conzen, M.P. (ed.): The Making of the American Landscape, Routledge, second edition, New York-London, pp. 253-278.

ZIMMERMAN, T.A. (1995): Roadside memorials in five south central Kentucky counties. Masters Theses \& Specialist Projects, Western Kentucky University, Bowling Green, $129 \mathrm{pp}$. 


\section{Shrnutí \\ PAMĚTNÍ KŘÍŽE V POLSKU: BĚŽNÝ, ALE SPORNÝ PRVEK VEŘEJNÝCH CEST}

Cílem článku je představit rozsah pamětních prvků podél polských silnic a názory Poláků na tento zvyk. Památníky podél cest jsou popisovány ze dvou hledisek - prostorového a společenského, přičemž se vychází z terénního výzkumu a multimediální analýzy obsahu. K výzkumu bylo zvoleno vojvodství Pomorskie, jeden ze 16 správních celků na severu Polska. V letech 2012 až 2014 byly provedeny terénní studie na různých veřejných silnicích $(623 \mathrm{~km})$. Dotazník nazvaný „Mají se pamětní kříže odstranit, aby nepřekážely u cest?“, realizovaný v listopadu 2011 novináŕi a státními zaměstnanci na webovém portálu www.trojmiasto.pl se specializací na zprávy v gdaňské aglomeraci, byl použit s cílem ukázat mínění veřejnosti, pokud jde o nezákonně postavené pomníčky u cest.

V terénní studii byl vyvrácen předpoklad uvedený v úvodu, že největší množství křížů se nalézá podél venkovských místních cest. Zaprvé, výzkum provedený autorkou prokázal, že na pomníčky u silnic lze narazit téměř dvakrát častěji podél silnic v gdaňské aglomeraci než podél venkovských cest. Zadruhé, ve venkovských oblastech se pomníčky podél cest vyskytují nejhojněji u nejnebezpečnějších státních silnic. Dále se objevují poněkud méně často podél méně nebezpečných krajských silnic na úrovni vojvodství, ovšem místní cesty $\mathrm{v}$ gminách a powiatech (okresech) je obsahují nejméně běžně. Při srovnání tohoto výsledku s dostupnými údaji o různých parametrech veřejných silnic v kraji, jež tu jsou podrobeny zkoumání, je nutno př́činu tohoto stavu hledat v rozdílech mezi mírou úmrtnosti na státních silnicích (nejvyšší), vojvodských silnicích (vysoká míra úmrtnosti) a mírou úmrtnosti na silnicích na úrovni gmin a powiatů (nejnižší míra).

Ze stovky zkoumaných pomníčků u silnic připadala většina na pamětní kříže (98\%). Veškeré zkoumané pamětní křiže byly v latině, což polské krajině podél silnic propůjčuje stejnorodý ráz. V Polsku odpovídá vysoká míra pamětních kř́ižů vysoké míre náboženské víry a pětadevadesátiprocentní příslušnosti k římskokatolické církvi.

Popřena byl i autorčina hypotéza uvedená v úvodu, podle níž pamětní kříže neobtěžují společnost, protože představují výraz pouta Poláků ke křest’anské tradici. Z internetových dotazníků vyplynulo, že názory na pamětní kříže se v polské společnosti štěpí na téměř dvě stejné poloviny: $52 \%$ Poláků chce, aby podél cest zůstaly, kdežto $48 \%$ je pro jejich odstranění. Navíc rozbor internetových diskusí ukázal, že společnost pokládá pamětní křiže bud’ za tradiční prvek silniční infrastruktury, anebo za předměty náboženského uctívání, případně symboly smrti a zármutku, jež nejsou vázány na určitou konkrétní kulturu. Zcela neočekávaně též platí, že reklamní předměty sloužily jako zásadní sporný bod jak pro odpůrce, tak zastánce odstranění kř́žů. Obecně je pravda, že odpůrcům vadily víc reklamní poutače, nebot představují větší hrozbu účastníkům silniční dopravy než malé pamětní křiže, jež jsou pro zastánce jejich odstranění prostě stejným rušivým momentem jako reklama.

Obr. 1 -Pamětní kříže podél silnic ve vojvodství Pomorskie. V legendě: hlavní státní silnice, silnice z terénní studie: na úrovni státu, vojvodství, powiatu a gminy; okresní města, vybraná města, památníky u cest.

Obr. 2 -Pamětní kř́iže podél státní silnice číslo 20 v Miszewku (severní Polsko). Pramen: autorčina fotografie, 2011.

Obr. 3 -Pamětní kříž na státní silnici číslo 20 v Rybakách (severní Polsko). Pramen: autorčina fotografie, 2014. 
Authors' affiliation: University of Gdańsk, Institute of Geography, Department of Spatial Management, ul. Bażyńskiego 4, 80-952 Gdańsk, Poland; e-mail: geolp@ug.edu.pl.

Initial submission, 2 October 2014; final acceptance 23 May 2015.

Please cite this article as:

PRZYBYLSKA, L. (2015): Memorial crosses in Poland: a commonplace and contested element of public roads. Geografie, 120, No. 4, pp. 507-526. 